\title{
The impact of adhering to sustainable harvesting guidelines on the total photosynthetic capacity of Taxus canadensis
}

\author{
by Sarah Martin ${ }^{1}$ and Manuel Lamontagne ${ }^{1, *}$
}

\begin{abstract}
Foliage of Canada yew (Taxus canadensis Marsh.) is commercially harvested for extracting taxanes used in anticancer pharmaceutical products. According to New Brunswick harvesting guidelines, only the last three years growth from four out of every five branches should be harvested. A study conducted in the understory of mixedwoods and tolerant hardwoods in northwestern New Brunswick estimated the impact of harvesting foliage on net photosynthetic activity of the residual plant. Net photosynthesis was measured on foliage of current to five-years-old in June, July and August to determine the contribution of each foliage age class to the photosynthetic capacity of a 6-year-old branch segment. Total biomass of each internode age class ( 0 to 5 and $\geq 6$-years-old) was measured to calculate the impact of tip harvesting on percentage of biomass removed and on photosynthetic capacity. When following New Brunswick harvesting guidelines, harvesting removed 15 to $17 \%$ of the last three years growth foliage which corresponds to 24 to $36 \%$ of total net photosynthetic capacity. The impact of harvesting is greater on photosynthetic activity than on biomass because it is the young and most photosynthetically active foliage that is harvested.
\end{abstract}

Keywords: impact of foliage harvesting; net photosynthesis; sustainable harvesting; Taxus canadensis; harvest simulation

\section{RÉSUMÉ}

L'if du Canada (Taxus canadensis Marsh.) est récolté commercialement pour l'extraction des composés chimiques utilisés dans la fabrication de produits pharmaceutiques anticancéreux. Selon le guide de récolte du Nouveau-Brunswick, seulement les trois dernières pousses annuelles doivent être récoltées sur $80 \%$ des branches. Létude fut réalisée dans le nordouest du Nouveau-Brunswick afin d'estimer l'impact de la récolte sur l'activité photosynthétique de larbuste résiduel. La photosynthèse nette fut mesurée sur le feuillage âgé de zéro à cinq ans en juin, juillet et août afin de déterminer la contribution de chaque classe dâge sur la capacité photosynthétique d'un segment de branche âgé de six ans. La biomasse totale du feuillage de chaque classe dâge ( 0 à 5 et $>6$ ans) fut également mesurée afin de simuler limpact de la récolte du feuillage sur le pourcentage de biomasse prélevée et sur la capacité photosynthétique. La récolte simulée prélève de 15 à $17 \%$ de feuillage chez les trois plus récentes classes dâge, ce qui correspond à 24 à $36 \%$ de la capacité photosynthétique totale. Limpact de la récolte est supérieur en ce qui concerne l'activité photosynthétique car c'est le feuillage jeune et plus productif qui est récolté.

Mots clés: impact cueillette du feuillage; simulation de récolte; photosynthèse nette; récolte durable; Taxus canadensis

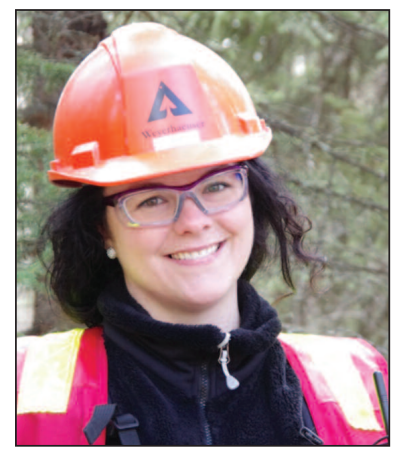

Sarah Martin

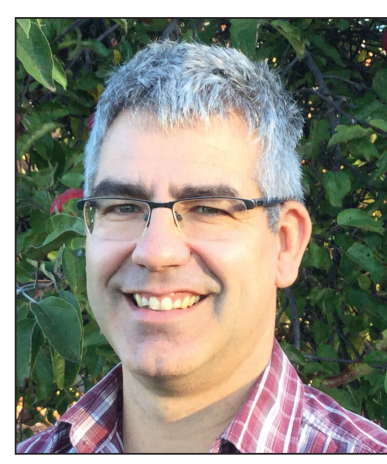

Manuel Lamontagne

\section{Introduction}

Canada yew (Taxus canadensis Marsh.) is a shade-tolerant evergreen shrub native to mixed and deciduous forest in northeastern North America (Windels and Flaspohler 2011). It reproduces primarily by layering (Allison 1991) and is most often found growing in clusters. Canada yew is a clonal species with two types of ramets, the most common has bilateral symmetry and alternate branching (Corradini et al. 2002). Canada yew produces upright branches up to $2 \mathrm{~m}$ (Windels and Flaspohler 2011) and they can retain their foliage up to eight years (Farrar 1999). Needles of Canada yew are linear, flat and attached along the stem (Pinto and Herr 2005).

In New Brunswick, Canada yew foliage has been harvested since 1996 by commercial harvesters for the extraction of tax-

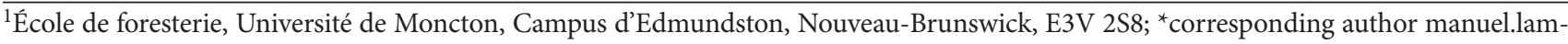
ontagne@umoncton.ca
} 
anes such as paclitaxel and docetaxel used in chemotherapy (Cameron et al. 2005). In 2005, worldwide demand for taxanes was 300 to $400 \mathrm{~kg} / \mathrm{year}$ and it was estimated that the demand would increase by 5-10\% per year (Cameron et al. 2005). Recent decisions from the United States Food and Drug Administration require that medications or substances from plants destined to be transformed into medication must come from a sustainable and controlled harvest method. Sustainable management of Canada yew is also important to continue future harvests of this important economic resource for the province (Cameron et al. 2005).

The Canadian Forest Service, Atlantic Forestry Centre, in association with the Department of Forest and Agriculture of Prince Edward Island, developed a sustainable harvesting method for Canada yew using an approach based on regrowth. The most recent edition of the harvesting guidelines recommends that for plants more than one metre in height, no more than three years of growth from the leader and the two or three lateral top branches should be removed. Moreover, the guidelines recommend that one in every five branches on the shrub be left uncut. The rotation period before returning to a harvest site should be four years (Smith et al. 2002). In the 1990s, harvesting occurred throughout the growing season and fall, but since taxane levels are lower in summer, harvesting is now done in the spring and fall when buds are dormant (Cameron et al. 2005). The CFS/PEI-recommended guidelines were adopted by the Canada Yew Association (www.canyew.org) and were recently tested in the field by Daigle (2004) in Quebec and Noland et al. (2011) in Ontario.

Several studies show that $50 \%$ defoliation of deciduous trees (Hoogesteger and Karlsson 1992), of deciduous shrubs (Willard and McKell 1978; Karolewski et al. 2010; da Silveira Pontes et al. 2012) and of evergreen species (Payton 1983; Reich et al. 1993; Haukioja et al. 1999; Lavigne et al. 2003; Piene 2003) represents a threshold at which growth and survival is no longer assured. Even where less than 50\% of Taxus canadensis foliage is removed, there is potential for significant impacts on growth and survival as a result of the high component of young productive tissue that is harvested, relative to older and less productive tissue that remains after harvest. The goal of this study was to estimate the impact of harvesting young foliage on the residual net photosynthetic activity of Taxus canadensis. The specific objective was to calculate the percent decline in photosynthetic capacity following the sustainable harvesting guidelines recommended in New Brunswick. To this end, we measured the photosynthetic capacity, specific leaf area and biomass of each internode of six-year-old branch segments in the growing season in June, July and August.

\section{Materials and Methods \\ Study area}

This study was established in 2004 at the Experimental Forest of the University of Moncton, Edmundston campus, School of Forestry. This forest covers 830 ha and is located near SainteAnne-de-Madawaska in northwestern New Brunswick (47 $20^{\prime} \mathrm{N}, 67^{\circ} 58^{\prime} \mathrm{W}$ ) in the Valley lowlands ecoregion and Blue Bell ecodistrict (Department of Natural Resources 2007). The mean annual temperature is $3.5^{\circ} \mathrm{C}$. Average annual precipita- tion is $1104 \mathrm{~mm}$ of which $30 \%$ falls as snow. The average frostfree period lasts 114 days and growing degree-days (above 5 ${ }^{\circ} \mathrm{C}$ ) are 1071 for June, July, and August (1981-2010 climate normal, Environment Canada 2014).

\section{Experimental design}

We selected five stands within a 500-m radius with abundant populations of Canada yew in the understory. Stands were either mature mixedwoods or tolerant hardwoods and ranged from 0.4 to 16.0 ha. According to stand type, the overstory was dominated by sugar maple (Acer saccharum (L.) Mill.), yellow birch (Betula alleghaniensis Britton), American beech (Fagus grandifolia Ehrh.) and balsam fir (Abies balsamea (L.) Mill.) with trembling aspen (Populus tremuloides Michx.), balsam poplar (Populus balsamifera L.), white spruce (Picea glauca (Moench) Voss), red maple (Acer rubrum L.) and eastern white-cedar (Thuya occidentalis L.) also present. The understory was dominated by Canada yew (Taxus canadensis Marsh.), wild lily-of-the-valley (Maianthemum canadense Desf.) and broom moss (Dicranum scoparium Hedw.). The surface deposit is an undifferentiated till. Soil texture is in the Holmesville series and varies from fine to medium welldrained and is classified as orthic humo ferric podzols (Soil Classification Working Group 1998). Observed browsing of Canada yew by deer (Odocoileus virginianus Zimmerman) or moose (Alces alces Linnaeus) was minimal or non-existant.

A ramet with a minimum height of $1 \mathrm{~m}$ was selected in each of the five stands and was representative of the population, and had at least one leader with a minimum of six internodes, including the growth of the current year. In 2004, sampling was carried out in June after budbreak, in July during the growing season and in August after budset. During each sampling month, six internodes - one for each age class from the current year shoot to the 5-year-old internode were measured and collected on a branch segment for a total of 30 internodes per month (6 internodes $\mathrm{x} 5$ shrubs $=30$ experimental units per month).

\section{Light-saturated net photosynthesis}

The light-saturated net photosynthesis rate (Amax) of the foliage was measured under saturating light $\left(1000 \mu \mathrm{mol} \mathrm{m} \mathrm{m}^{-2}\right.$ $\mathrm{s}^{-1}$ ) using a field-portable LI-6400 (Li-Cor, Nebraska, USA) gas exchange system. A halogen light supplied with a power supply unit (Shumacher PS-500-1A) was used to saturate the photosynthetic apparatus. A light response curve was carried out in one stand in June 2004 on one year-old foliage to determine the saturating light intensity before starting field measurements. The light saturation point was estimated at 860 $\mu \mathrm{mol} \mathrm{m} \mathrm{m}^{-2} \mathrm{~s}^{-1}$ with Photosyn Assistant (Version 1.2 Dundee Scientific).

In 2004, measurements of Amax were conducted in all stands on June $11^{\text {th }}$ and August $27^{\text {th }}$, on July $19^{\text {th }}$ for stands 1,3 and 4 , and on July $30^{\text {th }}$ for stands 2 and 5 . Since needles of Canada yew are attached along the stem, Amax corresponds to net photosynthesis of needles minus stem respiration. Amax measurements were first taken on current year needles and followed in order by older foliage. Samples were clipped between each measurement to enclose foliage of only one internode in the leaf chamber, and placed in a cooler to later measure leaf area at the laboratory. Samples were stored at $-18{ }^{\circ} \mathrm{C}$. 


\section{Specific leaf area (SLA)}

Needles were removed from the stem for each internode and scanned using WinSEEDLE 2002 software (Regent Instruments, Quebec) to measure leaf area. Needles and stem were then placed separately in an oven for 48 hours at $65{ }^{\circ} \mathrm{C}$ to obtain their dry mass. For each internode, we calculated the specific leaf area (SLA; $\mathrm{cm}^{2} \mathrm{~g}^{-1}$ ) as the ratio of needle leaf area to their dry mass (SLA needles ) and needle area to needle plus

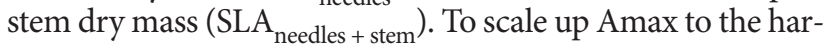
vested biomass, we used SLA measured per unit of area $\left(\mu \mathrm{mol} \mathrm{m} \mathrm{m}^{-2} \mathrm{~s}^{-1}\right)$ to per unit of mass $\left(\mu \mathrm{mol} \mathrm{g} \mathrm{g}^{-1}\right)$.

Biomass distribution and calculation of net photosynthetic capacity removed and left per age class

In May 2005 before budbreak, three shrubs per stand $(n=15)$ were harvested. Internodes of 0 to 5 , and all internodes older than five years were separated, oven dried for 48 hours at 65 ${ }^{\circ} \mathrm{C}$ and weighed.

Branching patterns of ideal plants had to be created to simulate harvesting since yew branching can vary between plants (Corradini et al. 2002). Six-year-old ideal shrubs with either alternate-distichous or monostichous branching patterns were created (Fig. 1). All axillary buds on each branch were considered as dormant except for the leader. According to the Canada yew harvesting method in New Brunswick, the last three internodes of the leader and of two or three vigorous lateral branches are harvested (Smith et al. 2002). The encircled parts of the branches in Fig. 1 illustrate harvesting for both branching patterns. Using the diagrams, it is possible to calculate the percentage of the numbers of harvested internodes (HI) by age class for both branching patterns (Table 1).

For a six year-old shrub with alternate-distichous branching pattern

(1) $\mathrm{HI}=(\mathrm{n}-6) / \mathrm{n} \times 4 / 5 \times 100$

For a six year-old shrub with monostichous branching pattern

(2) $\quad \mathrm{HI}=(\mathrm{n}-3) / \mathrm{n} \times 4 / 5 \times 100$

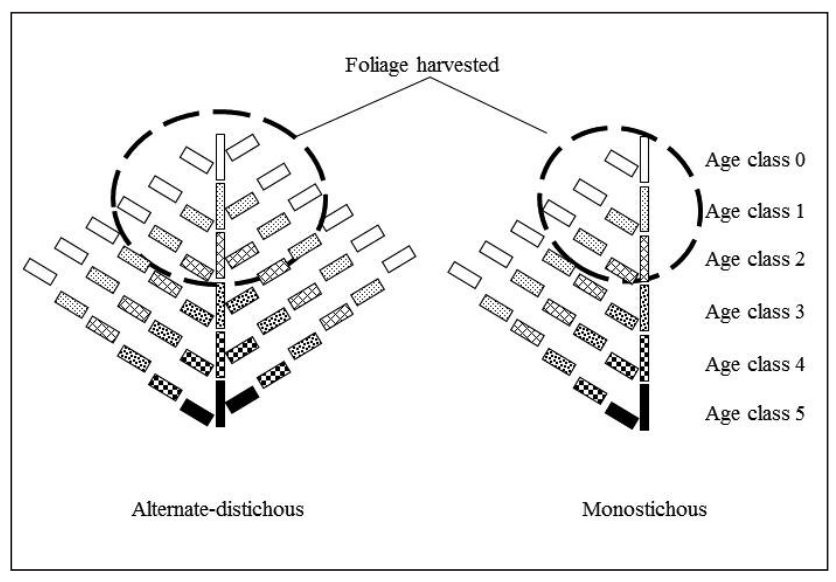

Fig. 1. Two models of a six-year-old Canada yew stem with an alternate-distichous and a monostichous branching pattern used for harvest simulation. Encircled foliage was harvested in our simulation.

Where $\mathrm{n}$ is the total of internodes by age class on an ideal six year-old shrub. The $4 / 5$ in the formula represents the harvest of four out of five branches as per the harvesting guidelines (Smith et al. 2002). As an example, $43 \%$ of the internodes of age class 0 are harvested on a six year-old shrub with distichous branching pattern since there are seven internodes harvested out of a total of thirteen.

To estimate the total percentage of net photosynthetic capacity removed and left on a six-year-old shrub following simulation of harvesting, we first calculated the percentage of net photosynthetic capacity of each age class "i” ( $\left.\mathrm{PC}_{\mathrm{i}}\right)$ as follows:

$$
\text { (3) } \quad \mathrm{PC}_{\mathrm{i}}(\%)=\frac{\mathrm{P}_{\mathrm{i}}\left(\mathrm{M}_{\mathrm{i}}\right)}{\sum \mathrm{P}_{\mathrm{i}}\left(\mathrm{M}_{\mathrm{i}}\right)} \times 100
$$

Where $P_{i}$ and $M_{i}$ are the net photosynthesic rate ( $\mu$ mol $\mathrm{g}^{-1} \mathrm{~s}^{-1}$ ) and the total dry mass of internode (foliage and stem in $g$ ) of the age class "i”, respectively. Second, we multiplied

Table 1. Percentage of harvested internodes $(\mathrm{HI})$ in each age class for a six year-old shrub with distichous or monostichous branching patterns, mean of total dry mass of the internode $\left(M_{i} ; n=15\right)$ and amount of biomass harvested $\left(M_{i} \times H I\right)$ in each age class

\begin{tabular}{|c|c|c|c|c|c|}
\hline \multirow[b]{2}{*}{ Age class } & \multicolumn{2}{|c|}{$\mathrm{HI}$} & \multirow{2}{*}{$\begin{array}{l}\mathrm{M}_{\mathrm{i}} \\
(\mathrm{g})\end{array}$} & \multicolumn{2}{|c|}{$\mathbf{M}_{\mathrm{i}} \mathbf{x} \mathrm{HI}$} \\
\hline & $\begin{array}{l}\text { distichous } \\
\text { (\%) }\end{array}$ & $\begin{array}{c}\text { monostichous } \\
(\%)\end{array}$ & & $\begin{array}{l}\text { distichous } \\
(\mathrm{g})\end{array}$ & $\begin{array}{c}\text { monostichous } \\
\text { (g) }\end{array}$ \\
\hline 0 & 43 & 46 & 7.0 & 3.0 & 3.2 \\
\hline 1 & 36 & 40 & 7.7 & 2.8 & 3.1 \\
\hline 2 & 27 & 32 & 8.6 & 2.3 & 2.8 \\
\hline 3 & 0 & 0 & 10.6 & 0.0 & 0.0 \\
\hline 4 & 0 & 0 & 10.3 & 0.0 & 0.0 \\
\hline \multirow[t]{3}{*}{5} & 0 & 0 & 9.5 & 0.0 & 0.0 \\
\hline & & Total (g) & 53.6 & 8.1 & 9.0 \\
\hline & & vested tip mass & 100.0 & 15.1 & 16.8 \\
\hline
\end{tabular}


Table 2. Percentage (and sum of percentage) of photosynthetic capacity of each age class before $\left(P C_{i}\right)$ and after $\left(R e s P C_{i}\right)$ simulation of harvesting internodes (HI) 0,1 and 2 for a six-year-old shrub with distichous or monostichous branching patterns

\begin{tabular}{|c|c|c|c|c|c|}
\hline \multirow[b]{2}{*}{ Age class } & \multirow{2}{*}{$\begin{array}{l}\mathrm{PC}_{\mathrm{i}} \\
(\%)\end{array}$} & \multicolumn{2}{|c|}{ HI } & \multicolumn{2}{|c|}{$\operatorname{ResPC}_{i}$} \\
\hline & & $\begin{array}{c}\text { distichous } \\
(\%)\end{array}$ & $\begin{array}{c}\text { monostichous } \\
(\%)\end{array}$ & $\begin{array}{c}\text { distichous } \\
(\%)\end{array}$ & $\begin{array}{c}\text { monostichous } \\
(\%)\end{array}$ \\
\hline \multicolumn{6}{|l|}{ June } \\
\hline 0 & -10.1 & 43 & 46 & -5.8 & -5.5 \\
\hline 1 & $60.2(74.1)$ & 36 & 40 & $38.5(50.2)$ & 36.1 (46.9) \\
\hline 2 & 24.0 & 27 & 32 & 17.5 & 16.3 \\
\hline 3 & 17.4 & 0 & 0 & 17.4 & 17.4 \\
\hline 4 & 5.8 & 0 & 0 & 5.8 & 5.8 \\
\hline 5 & 2.8 & 0 & 0 & 2.8 & 2.8 \\
\hline Total & 100.0 & - & - & 76.2 & 72.9 \\
\hline Total $\mathrm{PC}_{\mathrm{i}}$ removed & - & - & - & 23.8 & 27.1 \\
\hline \multicolumn{6}{|l|}{ July } \\
\hline 0 & 31.3 & 43 & 46 & 17.8 & 16.9 \\
\hline 1 & $39.6(86.4)$ & 36 & 40 & $25.3(54.4)$ & $23.7(51.2)$ \\
\hline 2 & 15.5 & 27 & 32 & 11.3 & 10.6 \\
\hline 3 & 9.2 & 0 & 0 & 9.2 & 9.2 \\
\hline 4 & 3.2 & 0 & 0 & 3.2 & 3.2 \\
\hline 5 & 1.2 & 0 & 0 & 1.2 & 1.2 \\
\hline Total & 100.0 & - & - & 68.0 & 64.8 \\
\hline Total $\mathrm{PC}_{\mathrm{i}}$ removed & 0 & - & - & 32.0 & 35.2 \\
\hline \multicolumn{6}{|l|}{ August } \\
\hline 0 & 45.3 & 43 & 46 & 25.8 & 24.5 \\
\hline 1 & $17.5(86.9)$ & 36 & 40 & $11.2(54.6)$ & $10.5(51.4)$ \\
\hline 2 & 24.1 & 27 & 32 & 17.6 & 16.4 \\
\hline 3 & 12.2 & 0 & 0 & 12.2 & 12.2 \\
\hline 4 & 1.6 & 0 & 0 & 1.6 & 1.6 \\
\hline 5 & -0.7 & 0 & 0 & -0.7 & -0.7 \\
\hline Total & 100.0 & - & - & 67.7 & 64.5 \\
\hline Total $\mathrm{PC}_{\mathrm{i}}$ removed & 0 & - & - & 32.3 & 35.6 \\
\hline
\end{tabular}

the percentage of net photosynthetic capacity of each age class "i" with the percentage of harvested internodes (HI) of each age class " $i$ " to obtain the percentage of harvested net photosynthetic capacity (Harv. PC $_{\mathrm{i}}$ ). Third, we obtained the percentage of residual net photosynthetic capacity of each age class "i" (Res. PC ) by subtracting the harvested capacity (Harv. $\mathrm{PC}_{\mathrm{i}}$ ) from the total capacity $\left(\mathrm{PC}_{\mathrm{i}}\right)$. By summation, we obtained the total percentage of net photosynthetic capacity removed and left at the shrub level. These calculations were carried out for each month.

\section{Statistical analysis}

A mixed linear model was fitted for each sampling month to examine the effect of age class on Amax (expressed on both a leaf area $\left(\mu \mathrm{mol} \mathrm{m} \mathrm{m}^{-2} \mathrm{~s}^{-1}\right)$ and on a dry mass $\left(\mu \mathrm{mol} \mathrm{g} \mathrm{g}^{-1} \mathrm{~s}^{-1}\right)$ basis), SLA needles $_{\text {and SLA }}$ needles + stem. Age class was a fixed factor with six levels while branch segment was considered as a random block factor to take into account the serial correlation expected across age classes. The statistical model was as follow:

$$
y i=\mu+\alpha+\beta+\alpha \beta+\varepsilon
$$

Data were checked for normality and homogeneity of variances with Kolmogorov-Smirnov's test and Levene's test, respectively. Tukey's HSD test was used for means comparison with a $5 \%$ significance level $(\alpha=0.05)$. Statistical analyses were performed using SPSS 11.0 (LEAD Technologies Inc). No statistical tests were carried out on harvest simulations.

\section{Results}

Light-saturated net photosynthesis [Amax)

When Amax was expressed on a leaf area basis, Amax of current internodes (age class 0 ) was significantly lower than oneyear-old internodes in June and July ( $p \leq 0.001$ in both cases) (Fig. 2A). Otherwise, Amax decreased significantly with increasing age class, but the age class effect was not statistically significant in August $(p=0.057)$.

Age class had a significant effect in June, July and August ( $p \leq 0.01$ for the three months) when Amax was expressed on a dry mass unit (Fig. 2B). For each month, Amax decreased significantly with increasing age class, except for the current internodes in June. In this latter case, Amax was negative due to high respiration of immature tissue. 


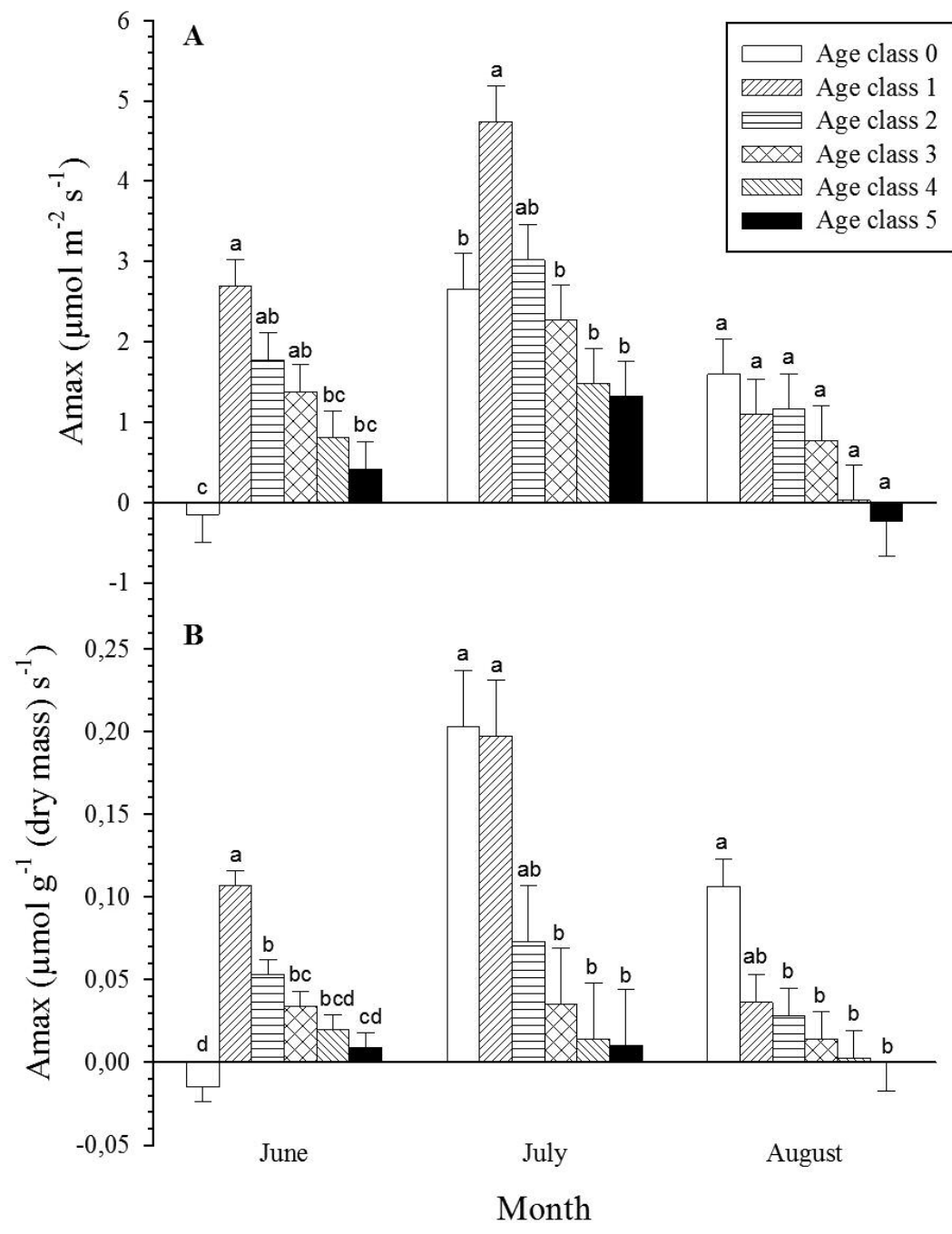

Fig. 2. Mean values and SE of $\mathbf{A}$ light-saturated net photosynthesis per leaf area unit ( $\mu \mathrm{mol} \mathrm{m} \mathrm{m}^{-2} \mathrm{~s}^{-1}$ ) and B) light-saturated net photosynthesis per dry mass unit ( $\mu \mathrm{mol} \mathrm{g} \mathrm{g}^{-1} \mathrm{~s}^{-1}$ ) for six Canada yew needle age classes in June, July and August 2004; values with different letters within each month are significantly different.

\section{Specific leaf area (SLA)}

A significant effect of age class was observed in June, July and August ( $p \leq 0.001$ for the three months) when SLA was expressed on a needles mass basis (SLA $\mathrm{Seedles})$ (Fig. $3 \mathrm{~A})$. A significant effect of age class was also observed in June, July and August ( $p \leq 0.001$ for the three months) when SLA was calculated with stem mass $\left(\mathrm{SLA}_{\text {needles }+ \text { stem }}\right)$ (Fig. 3B).

For each month, SLA ${ }_{\text {needles }}$ and SLA $A_{\text {needles + stem }}$ decreased with age class. However, the difference between age classes was more pronounced for SLA $A_{\text {needles + stem }}$ since stem weight increased disproportionally more than needle weight with increasing age class.

Percentage of harvested tip mass and photosynthetic contribution For a six-year-old shrub, the percentage of harvested tip mass varied between 15 to $17 \%$ for distichous or monostichous branching patterns, respectively (Table 1). The total percent- age of photosynthetic contribution $\left(\mathrm{PC}_{\mathrm{i}}\right)$ of age classes 0,1 and 2 were $74 \%, 86 \%$ and $87 \%$ respectively, from June to August before harvesting (Table 2). After harvesting, the internodes of age classes 0,1 and 2 still contributed to more than $50 \%$ of the photosynthesis, except for a monostichous branching pattern considered in June, where age classes 0,1 and 2 contributed only $47 \%$ (Table 2). However, total $\mathrm{PC}_{\mathrm{i}}$ removed after harvest simulation was always lower than $36 \%$.

\section{Discussion}

Light saturated net photosynthesis and specific leaf area

Canada yew maintains its needles for eight years (Farrar 1999) and shows a decline in photosynthesis with needle age (Fig. 2). Many studies show that the photosynthetic capacity of needles decreases with increasing age for conifers such as Abies balsamea and Picea glauca (Clark 1961), Picea mariana (Mill.) BSP, (Hom and Oechel 1983), Pinus pinaster Aiton (Warren 2006), Abies concolor Lindley ex Hildebrand, Picea pungens Engelm., Pinus nigra Arnold, Pinus ponderosa Dougl. ex P. \& C. Lewis, Pinus strobus L. and Pinus sylvestris L. (Freeland 1952). According to Warren (2006), this variation in photosynthesis with needle age is not caused by the internal $\mathrm{CO}_{2}$ conductance or by the reduction of stomatal conductance but is connected to a decrease of the photosynthetic rate per nitrogen unit and the specific activity of rubisco. In our case, we should not forget the respiration cost of the stem on internode photosynthesis during measurements. Thus, we consider that the respiration of the stem increased with increasing age and the increasing biomass of the stem as shown by the difference between SLA $A_{\text {needles }+ \text { stem }}$ and SLA $A_{\text {nee- }}$ dles (Fig. 3).

Negative Amax for age class 0 in June can be explained by the fact that foliage was young, not yet lignified and still a carbon sink as shown (although not statistically tested) by decreasing SLA $_{\text {needles }}$ over time (Fig. 3). A high respiration rate is associated with fast growth in immature tissues which results in a reduction in net photosynthesis. Moreover, since needles are only partially deployed, increased mutual shading among the needles can contribute to producing a negative photosynthetic rate of the new shoots early in the season (Clark 1961). The age class 0 needles had the highest Amax in July and August when foliage was fully mature, similar to that reported for Abies balsamea and Picea glauca (Clark 1961). 


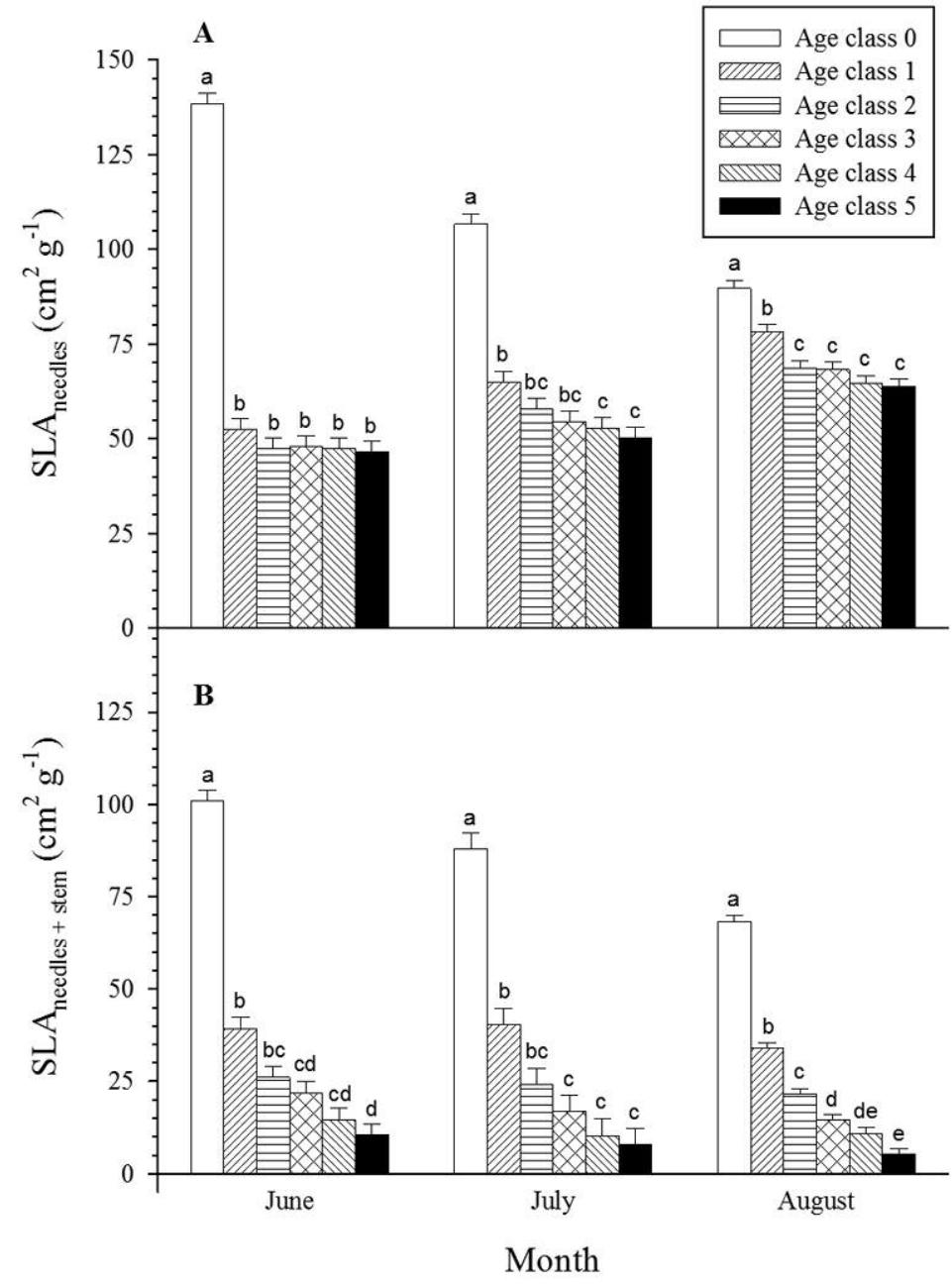

Fig. 3. Mean values and SE of AJ specific leaf area based on needle dry mass and B) specific leaf area based on needle + stem dry mass for six Canada yew needle age classes in June, July and August 2004; values with different letters within each month are significantly different.

\section{Percentage of PCi removed following harvest simulations} Our simulations show that the method of yew harvesting employed in New Brunswick removes less than $17 \%$ of the total dry mass (foliage and stem) (Table 1) and between $24 \%$ and $36 \%$ of the net photosynthesis on a six-year-old shrub with either alternate-distichous or monostichous branching patterns (Table 2). These results suggest that harvesting the three last internodes according to the New Brunswick harvesting guidelines will not cause significant impacts on growth of Canada yew due to low harvest intensity. When Canada yew was harvested in central Ontario according to the present harvesting guidelines, harvested plants replaced the amount of biomass removed within three to four years (Noland et al. 2011), suggesting sustainability. Daigle (2004) studied the impact of four harvest intensities (control, low, moderate and severe) and three harvest periods (June, September and October) on the regrowth of Canada yew in Quebec. One year after treatment application, he observed that the best regrowth occurred when following the present harvesting guidelines (low harvest intensity). He also observed that harvest timing did not significantly influence the total current-year shoot biomass per stem produced the following year. However, there was a tendency for more biomass produced when foliage was harvested in June.

Results from artificial defoliation, tip harvesting or pruning for other coniferous tree species generally show adequate regrowth when treatments are of low intensity. Studies of artificial defoliation showed that 50\% removal of the current year's needles increased the production of new growth on twelve year-old Picea glauca (Piene 2003) and did not alter production of new foliage for seedlings of Pinus resinosa Ait. (Haukioja et al.1999). Seedlings of $P$. resinosa defoliated by $25 \%$ were even larger than controls at harvest time. Gasser and Swift (2014) did not consider that tip harvesting of balsam fir for the bough industry was detrimental for the tree when harvesting $\leq 20 \%$ of foliage biomass. Finally, Hinesley and Derby (2004) observed, compared to controls, a reduction of Christmas tree growth (Abies fraseri (Pursh) Poir.) of 37\% and 53\% when shearing annually distal tips in July and October, respectively. However, annual shearing increased crown density and improved the market value of the trees.

To our knowledge, there is no threshold for the level of photosynthesis to be preserved. The harvesting of old foliage of Abies balsamea stimulates net photosynthesis in the current year's growth and this probably improves the nitrogen relations in the needles (Lavigne et al. 2003). According to Hoogesteger and Karlsson (1992), photosynthetic activity of the remaining foliage of Betula pubescens Ehrh. is also stimulated after $50 \%$ defoliation, producing $35 \%$ more photosynthesis compared to control trees, suggesting a source-sink modification. Therefore, growth after defoliation is compensated by carbohydrate reserves or carbon reallocation or both (Hoogesteger and Karlsson 1992). Due to such compensatory mechanisms known in plants, the real impact of harvesting Canada yew on photosynthetic capacity might be much lower than suggested by the current study's observed results. This could explain the vigour of the regrowth observed after the harvesting on other studies (Daigle 2004; Noland et al. 2011).

\section{Conclusion}

The normative harvest of yew foliage appears sustainable as it removes less than $17 \%$ of biomass and less than $36 \%$ of the net 
photosynthetic capacity of the plant. The impact of harvesting is greater on photosynthetic activity than on biomass because it is the young and most photosynthetically active foliage that is harvested. However, compensatory mechanisms can lessen the overall effect of such reduction in photosynthetic capacity. It is important to note that foliage harvesting might not be sustainable in areas where deer are abundant since browsing significantly reduces yew density (Allison 1990) and survival (Holmes el al. 2009).

To better understand the impact of tipping on yew, we suggest that the photosynthetic response, carbon metabolism and carbohydrate storage dynamics should be studied along a gradient of plant size and light availability.

\section{Acknowledgments}

The authors would like to thank Karl Roussel and Sébastien Therrien for technical assistance in the field and in the laboratory, Alain Laplante, Director of the Experimental Forest of the Faculty of Forestry at the University of Moncton, Edmundston Campus for his collaboration, and Dodick Gasser and two anonymous reviewers for their valuable comments.

\section{References}

Allison, T.D. 1990. The influence of deer browsing on the reproductive biology of Canada yew (Taxus canadensis Marsh.). II. Pollen limitation: An indirect effect. Oecologia 83: 530-534.

Allison, T.D. 1991. Variation in sex expression in Canada yew (Taxus canadensis). Am. J. Bot. 78: 569-578.

Cameron, S.I., R.F. Smith and K.E. Kierstead. 2005. Linking medicinal/nutraceutical products research with commercialization. Pharm. Biol. 43: 425-433.

Clark, J. 1961. Photosynthesis and respiration in white spruce and balsam fir. Syracuse University, Syracuse, New York. 72 p.

Corradini, P., C. Edelin, A. Bruneau and A. Bouchard. 2002. Architectural and genotypic variation in the clonal shrub Taxus canadensis as determined from random amplified polymorphic DNA and amplified fragment length polymorphism. Can. J. Bot. 80: 205-219.

Daigle, R. 2004. Effet de l'intensité et du moment de la coupe sur la teneur en taxanes, la masse et la longueur de la repousse de l'if du Canada (Taxus canadensis Marsh.) un an après la coupe. Mémoire de maîtrise. Université Laval, Québec (Québec). 75 p.

da Silveira Pontes, L., D. Magda, M. Jarry, B. Gleizes and C. Agreil. 2012. Shrub encroachment control by browsing: Targeting the right demographic process. Acta Oecologica 45: 25-30.

Department of Natural Resources. 2007. Our landscape heritage: The story of ecological land classification in New Brunswick. Department of Natural Resources, Province of New Brunswick, Fredericton, New Brunswick, Canada.

Environment Canada. 2014. Rapport de données climatiques quotidiennes. http://climat.meteo.gc.ca (March 10 ${ }^{\text {th }} 2014$ )

Farrar, J.L. 1999. Les arbres du Canada. FIDES et le Service Canadien des Forêts division Ressources Naturelles Canada. Ottawa, Ontario. 502 p.

Freeland, R.O. 1952. Effect of age of leaves upon the rate of photosynthesis in some conifers. Plant Physiol. 27: 685-690.

Garnier, E., B. Shipley, C. Roumet and G. Laurent. 2001. A standardized protocol for the determination of specific leaf area and leaf dry matter content. Funct. Ecol. 15: 668-695.
Gasser D. and D. E. Swift. 2014. Initial effects of intensity and severity of balsam fir tip harvesting on harvesting intensity at the stand level, tip production, and tip/foliage removal at the tree level, and harvesters' production and productivity. J. Sustain. Forest. 33: 99-126.

Haukioja, E., T. Honkanen and V. Kitunen. 1999. Responses of Pinus sylvestris branches to simulated herbivory are modified by tree sink/source dynamics and by external resources. Funct. Ecol. 13: 126-140.

Hinesley, L.E. and S.C. Derby. 2004. Growth of Fraser fir Christmas trees in response to annual shearing. HortScience 39: 1644-1646.

Holmes, S.A., C.R. Webster, D.J. Flaspohler and R.E. Froese. 2009. Death and Taxus: The high cost of palatability for a declining evergreen shrub, Taxus canadensis. Can. J. Forest Res. 39: 1366-1374.

Hom, J.L. and W.C. Oechel. 1983. The photosynthetic capacity, nutrient content, and nutrient use efficiency of different needle ageclasses of black spruce (Picea mariana) found in interior Alaska. Can. J. Forest Res. 13: 834-839.

Hoogesteger, J. and P.S. Karlsson. 1992. Effects of defoliation on radial stem growth and photosynthesis in the mountain birch Betula pubescens ssp. tortuosa. Funct. Ecol. 6: 317-323.

Karolewski, P., M. Zadworny, J. Mucha, A. Napierala-Filipiak and J. Oleksyn. 2010. Link between defoliation and light treatments on root vitality of five understorey shrubs with different resistance to insect herbivory. Tree Physiol. 30: 969-978.

Lavigne, M.B., C.H.A. Little and D.P. Ostaff. 2003. Impact of old foliage removal, simulating defoliation by the balsam fir sawfly, on balsam fir tree growth and photosynthesis of current-year shoots. Forest Ecol. Manag. 186: 261-269.

Noland, T.L., L. Rich and M.S. Packalen. 2011. Establishing a sustainable harvest for Canada yew (Taxus canadensis Marsh.) in Ontario. Forest. Chron. 87: 529-536.

Payton, I.J. 1983. Defoliation as means of assessing browsing tolerance in Southern Rata (Metrosideros umbellata) Pacific Sci. 37: 443-452.

Piene, H. 2003. Growth recovery in young plantation white spruce following artificial defoliation and pruning. Can. J. Forest Res. 33: 1267-1275.

Pinto, F. and D. Herr. 2005. Autecology of Canada yew (Taxus canadensis Marsh.). Southern Science and Information Section Technical Note \#12. Ontario Ministry of Natural Resources, North Bay, Ontario. 7 p.

Reich, P.B., M.B. Walters, S.C. Krause, D.W. Vanderklein, K.F. Raffa and T. Tabone. 1993. Growth, nutrition and gas exchange of Pinus resinosa following artificial defoliation. Trees Struct. Funct. 7: 67-77.

Smith, R., B. Glen and P. McKnight. 2002. Ground Hemlock Harvesting Guidelines. Natural Resources Canada, Canadian Forest Service and Prince Edward Island Department of Agriculture and Forestry. 4 p.

Soil Classification Working Group. 1998. The Canadian System of Soil Classification. $3^{\text {rd }}$ ed. Agriculture and Agri-Food Canada \# $1646,187 \mathrm{p}$

Warren, C.R. 2006. Why does photosynthesis decrease with needle age in Pinus pinaster? Trees Struct. Funct. 20: 157-164.

Willard, E.E. and C.M. McKell. 1978. Response of shrubs to simulated browsing. J. Wildl. Manage. 42: 514-519.

Windels, S.K. and D.J. Flaspohler. 2011. The ecology of Canada Yew (Taxus canadensis Marsh.): A review. Botany 89: 1-17. 